\title{
A mini review on challenges and opportunities in dinoflagellates cultivation
}

\author{
Carlos Y. B. Oliveira*, Renata S. Farias, Jéssika L. Abreu, Deyvid Oliveira, Elizabeth P. Santos, Laenne B. S. \\ Moraes and Alfredo 0. Gálvez
}

Departamento de Pesca e Aquicultura, Universidade Federal Rural de Pernambuco, Recife, Brazil

*Corresponding author: yureboliveira@gmail.com

\begin{abstract}
Dinoflagellates are photosynthetic protists commonly distributed in marine and freshwater environments and can be found in symbiotic associations. They are a significant primary producer and play a fundamental role in the functioning of aquatic ecosystems - especially for coral reefs. Dinoflagellates can produce a wide variety of secondary metabolites, and their toxins can affect fish, birds and mammals. In recent years these toxins have been found to have potential cytotoxic, anticancer, antibiotics, antifungals activities. This mini review covers the main genera of dinoflagellates, and challenges and advances in their cultivation in addition to prospects for development of dinoflagellates-based products.
\end{abstract}

Keywords: Microalgae, Biomass, Secondary metabolites, Toxins

\section{Background}

Interest in microalgae has increased considerably in recent decades, mainly due to demand for sustainable biomass and bioprocesses, such as aquaculture, where microalgae play essential roles as live food for molluscs, and larvae of crustaceans and fish (Muller-Fuega, 2000; Garrido-Cardenas et al., 2018). Besides other applications, these photosynthetic microorganisms have also aroused interest in wastewater treatment and production of high commercial value molecules (eg., fatty acids, carotenoids and amino acids ) and biofuels (Daroch et al., 2013; Salama et al., 2017; Oliveira et al., 2020a). According to Garrido-Cardenas et al. (2018), even with various species of microalgae isolated, global production of and research on microalgae are limited to a small number of taxa, such as Arthrospira of Spirulina group, that are intended mainly for human food or as a dietary supplement (Pan-Utai et al., 2018); Chlorella spp. for being a potential producer of $\beta$-1,3-glucan, an active immunostimulator with antioxidant capacity (Carballo et al., 2019); Dunaliella salina, as a source of $\beta$-carotene (BenAmotz, 2004) and; Haematococcus pluvialis, for astaxanthin extraction (Panis \& Carreon, 2016).

Dinoflagellates are a eukaryotic group of microalgae common in marine, estuarine and freshwater environments. Besides the species diversity (around 6,000 species), dinoflagellates have various structural shapes (amoeboid, coccoid, palmelloids, etc.), habitats (planktonic, benthic and epicontinental) and nutritional modes (photoautotrophic, heterotrophic, mixotrophic and phagotrophy). They play a significant role as primary producers and contribute to the functioning of aquatic ecosystems, especially coral reefs. The ecological activities of coral reefs heavily depend on the symbiosis between reef-building corals and zooxanthellae (reviewed in Jephcott et al., 2016 and Suggett et al., 2017).
In addition, dinoflagellates also receive interest in research because some of their species produce toxins and they also cause harmful algal blooms (HABs) (Gravinese et al., 2018). Despite their great diversity, about 90 species have been reported as potential toxin producers (Burkholder et al., 2008; González-Rodríguez et al., 2010; Speight \& Henderson, 2010; Saldarriaga \& Taylor, 2017).

Toxins from dinoflagellates can affect human and ecosystem health and, for a long time, this was the main reason for interest in their studies. However, in recent years dinoflagellate toxins have been found to have potential pharmaceutical applications (i.e. cytotoxic, anticancer, antibiotics, antifungals activities). In this context, this mini review reveals key information about dinoflagellates cultivation. The discussion also takes into account the major challenges, new insights and potential of the biomass production of dinoflagellates.

\section{Dinoflagellate Genera}

Specific dinoflagellate genera have been studied as a source of bioactive molecules (secondary metabolites): Alexandrium, Amphidinium, Gymnodinium, Karlodinium and Symbiodinium (Wang \& Hsieh, 2002; Parker et al., 2002; Band-Schmidt et al., 2014; Benstein et al., 2014; Lage et al., 2014; Molina-Miras et al., 2018; Langenbach \& Melkonian, 2019).

\subsection{Alexandrium}

The genus Alexandrium is one of the major harmful algal bloom genera. Three different families of toxins were reported in this genus: saxitoxins (STX), goniodomins and spirolides; but they have not been fully characterized (Balech, 1989; Touzet et al., 2008; reviewed in Anderson et al., 2012). Alexandrium spp. are considered opportunistic in relation to nutrition - different species have been found in both nutrient- 
rich (Spatharis et al., 2007) and nutrient-poor waters (Collos et al., 2014). In addition, bacteria and microalgae (dinoflagellate, Amphidinium carterae) have been observed to contain food vacuoles (reviewed in Jeong et al., 2010). Moreover, growth under the mixotrophic nutritional mode has also been reported for Alexandrium catenella (Legrand \& Carlsson, 1998).

\subsection{Amphidinium}

Amphidinium spp. are toxic dinoflagellates found in coastal waters and tempered tropical estuaries (Steidinger \& Jangen, 1996). It is known for HABs that may produce mainly ichthyotoxins (Huang et al., 2009) and hemolytic substances (Echigoya et al., 2005). Abundance of peridinin (an apocarotenoid), located in the photosynthetic complex of most dinoflagellates, has been extensively studied in Aphidinium carterae (Hofmann et al., 1996); this apocarotenoid possesses strong antioxidant properties and can act against the tumors (Nishino, 1998; Barros et al., 2001). Recently, amphidinols (APDs), secondary metabolites produced by this genus, have aroused a growing interest by presenting potential antifungal, antibacterial, antioxidant and antitumor agents (Satake et al., 2017; Iwamoto et al., 2017; Martínez et al., 2019). Although the structure of APDs is welldocumented (Satake et al., 2017), several factors related to the biosynthesis of these molecules are still not well understood.

\subsection{Gymnodinium}

Gymnodinium catenatum is the only dinoflagellate species of this genus that produces paralytic shellfish poisoning (PSP) and its greatest relevance is due to the fact that it can affect human health with neurological and gastrointestinal disorders, usually as a result of the consumption of contaminated shellfish (Band-Schmidt et al., 2008; Martínez et al., 2016). This species is widespread in temperate and tropical waters in many regions of the world (Hallegraeff et al., 2012) and the toxin profile may vary according to environmental factors (Negri et al., 2001; Oliveira-Proença et al., 2001; Holmes et al., 2002; Oh et al., 2010). As for the other dinoflagellates, studies on $G$. catenatum have mainly involved the ecophysiological approach for understanding the influence of environmental factors on the production of toxins.

\subsection{Karlodinium}

In the genus Karlodinium, a cosmopolitan species of temperate regions that has been more thoroughly studied is Karlodinium veneficum (García-Camacho et al., 2007; Gallardo-Rodríguez et al., 2012; López-Rosales et al. 2015). $K$. veneficum is a producer of karlotoxins (KmTxs) and it can feed by ingesting diatoms and copepods (Bachvaroff et al., 2009; Waters et al., 2010; Place et al., 2012). The KmTxs can be easily isolated, and like APDs, it has hemolytic and ichthyotoxic activity. KmTxs are also more likely to function as anti-grazing and allelopathic. Investigations have shown that $K$. veneficum is able to reconfigure its cellular metabolic machinery and regulate dynamic protein expressions to cope with the stress caused by excess light. This is an interesting strategy for intensive cultivation to produce biomass (Cui et al., 2017). For this reason, $K$. veneficum proves to be a promising species for production of biomolecules.

\subsection{Symbiodinium (family Symbiodiniaceae)}

Symbiodinium spp. were recognized by arbitrary letters (e.g., A, B, C) that became referred to as "clades". Recently, in short, the genus Symbiodinium, based on genetics and ecology data, was split into seven new genera belonging to family Symbiodiniaceae, (LaJeunesse et al. 2018). Regardless of taxonomic classification, they are commonly approached for their endosymbiotic association with coral reefs (but they can also be associated with some species of anemones, jellyfish, sponges and others) (reviewed in Stat et al., 2006; Krueger \& Gates, 2010). For these associations, most studies have sought to investigate the effect of environmental parameters on endosymbiosis with coral reefs and to clarify the main causes involved in coral bleaching events (McIlroy et al., 2016; Grégoire et al., 2017; Bernasconi etal., 2019). However, peridinin and toxins contents have also aroused, albeit simple, interest in cultivation aimed at the biotechnological applications of Symbiodinium spp. biomass (Benstein et al., 2014; Langenbach \& Melkonian, 2019; Tsirigoti et al., 2020).

\section{Biomass Production}

Difficulties in reaching high biomass concentrations in cultures of dinoflagellates limit the commercial applications. This is mainly due to the sensitivity of many dinoflagellates to shear forces. Recently, the application of twin-layer porous substrate bioreactor (TL-PSBR) has been investigated in the laboratory. However, although projections are commonly made for large TL-PSBR ( $\mathrm{g} \mathrm{m}$-2), operation of this bioreactor on an industrial scale is still doubtful (Langenbach \& Melkonian, 2019). In addition to the TL-PSBR, bubble column photobioreactors (BC-PBR) have been used successfully for the biomass production of dinoflagellates (López-Rosales et al. 2016, 2017). The BC-PBR also controls shear stress, ensuring healthy growth of dinoflagellate cells. Moreover, the BC-PBR is likely to be more productive than the TL-PSBR because they have a larger photosynthetically active area than the biofilm of TL-PSBR. The improvement of photobioreactors for the intensive cultivation of dinoflagellates is still a basic process necessary for the development of this production chain.

\section{Potential Aplications in Aquaculture and Future Directions}

Due to the production of allelopathic compounds and the ability to grow under mixotrophic nutritional mode the dinoflagellates have a great potential to treat wastewaters. The microalgae, because of their use in wastewater treatment, have attracted increasing attention; they can 
convert inorganic compounds into polyunsaturated fatty acids (PUFA), carotenoids, amino acids and others biomolecules, in addition to the secondary metabolites (Zeller et al., 2013; Oliveira et al. 2020b). This potential has not been sufficiently explored (Molina-Miras et al. 2020). In the case of PUFA, particularly docosahexaenoic acid (DHA) and eicosapentaenoic acid (EPA), exhibit biological activities and are considered in the treatment of heart disease, cancer, type 1 diabetes and others (reviewed in Mendes et al., 2009). Hitherto, fish oil is the most widely used product of this category in the market even with some negative characteristics (e.g. distracting odor, allergic reactions, high refinery costs etc.). In addition, this use amounts to unsustainable exploitation of wild prey fish in aquaculture of fish and shrimp feed (Naylor et al., 2000). Based on this potential, a simplified model for production of dinoflagellate biomass using aquaculture wastewater is shown in Figure 1.

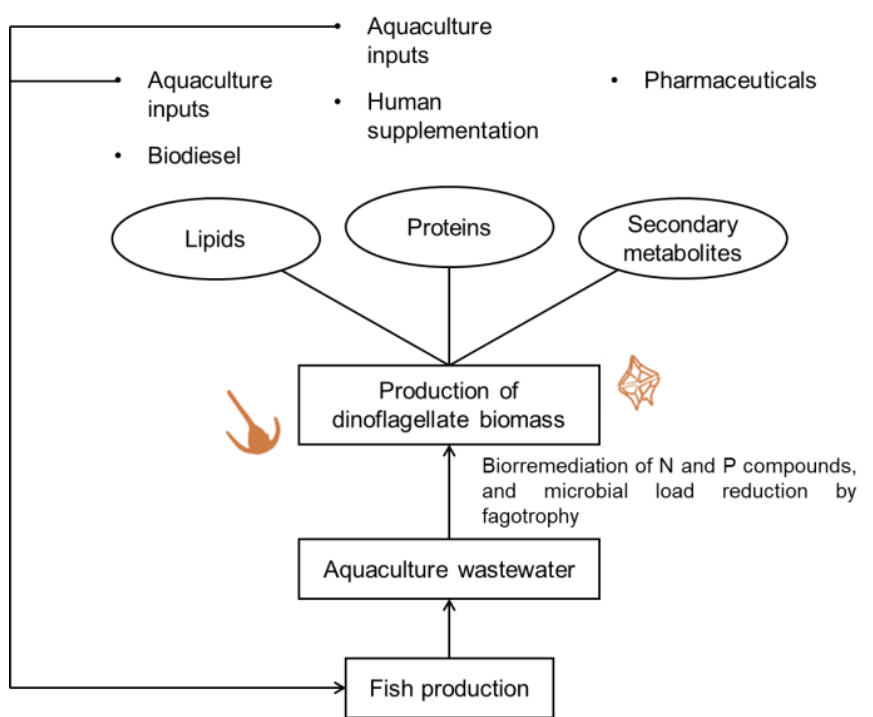

Figure 1. Simplified integrated model for the production of dinoflagellate biomass using aquaculture wastewater.

Recent interest in the cultivation of dinoflagellates has already resulted in substantial improvements and technological advances in the production processes. Limitation on commercial application of pigments and secondary metabolites produced by dinoflagellates is due to the lack of a reliable natural source of these macromolecules, since industrial-scale cultivation of dinoflagellates still faces barriers. Addressing some of these constraints will be a significant step towards the large-scale development of new inputs and drugs.

\section{Acknowledgement}

This study was financed in part by Coordenação de Aperfeiçoamento de Pessoal de Nível Superior - Brasil Finance Code 001 and AOG is thankful to Conselho Nacional de Desenvolvimento Científico e Tecnológico (CNPq) (PQ 308063/2019-8).

\section{References}

Anderson, D.M., Alpermann, T.J., Cembella, A.D., Collos, Y., Masseret, E. \& Montresor, M. (2012). The globally distributed genus Alexandrium: multifaceted roles in marine ecosystems and impacts on human health. Harmful Algae 14: 10-35.

Bachvaroff, T.R., Adolf, J.E., Place \& A.R. (2009). Strain variation in Karlodinium veneficum (Dinophyceae): toxin profiles, pigments, and growth characteristics. Journal of Phycology 45: 137-153.

Balech, E. (1989). Redescription of Alexandrium minutum Halim (Dinophyceae) type species of the genus Alexandrium. Phycologia 28(2): 206-211.

Band-Schmidt, C. J., Rojas-Posadas, D. I., Morquecho, L. \& HernándezSaavedra, N. Y. (2008). Heterogeneity of LSU rDNA sequences and morphology of Gymnodinium catenatum dinoflagellate strains in Bahía Concepción, Gulf of California, Mexico. Journal of Plankton Research 30(7): 755-763.

Band-Schmidt, C.J., Bustillos-Guzmán, J.J., Hernández-Sandoval, F.E., Núñez-Vázquez, E.J. \& López-Cortés, D. J. (2014). Effect of temperature on growth and paralytic toxin profiles in isolates of Gymnodinium catenatum (Dinophyceae) from the Pacific coast of Mexico. Toxicon 90: 199-212.

Barros, M. P., Pinto, E., Colepicolo, P. \& Pedersén, M. (2001). Astaxanthin and peridinin inhibit oxidative damage in Fe2+-loaded liposomes: scavenging oxyradicals or changing membrane permeability? Biochemical and Biophysical Research Communications 288(1): 225-232.

Ben-Amotz, A. (2004). Industrial production of microalgal cell-mass and secondary products-major industrial species. In: Handbook of Microalgal Culture: Biotechnology and applied phycology. Blackwell science Ltd, v. 273 , p. $273-280$

Benstein, R.M., Çebi, Z., Podola, B. \& Melkonian, M. (2014). Immobilized growth of the peridinin-producing marine dinoflagellate Symbiodinium in a simple biofilm photobioreactor. Marine Biotechnology 16(6): 621-628.

Bernasconi, R., Stat, M., Koenders, A. \& Huggett, M.J. (2019). Global networks of Symbiodinium-bacteria within the coral holobiont. Microbial Ecology 77(3), 794-807.

Burkholder, J.M., Glibert, P.M. \& Skeltona, H.M. (2008). Mixotrophy, a major mode of nutrition for harmful algal species in eutrophic waters. Harmful Algae 8, 77-93.

Carballo, C., Pinto, P. I. S., Mateus, A. P., Berbel, C., Guerreiro, C. C., Martinez-Blanch, J. F., Codoñer, F. M., Mantecon, L., Power, D. M. \& Manchado, M. (2019). $\beta$-glucans and microalgal extracts modulate the immune response and gut microbiome in Senegalese sole (Solea senegalensis). Fish \& Shellfish Immunology 92(9), 31-39.

Collos, Y., Jauzein, C., Ratmaya, W., Souchu, P., Abadie, E., \& Vaquer, A (2014). Comparing diatom and Alexandrium catenella/tamarense blooms in Thau lagoon: Importance of dissolved organic nitrogen in seasonally $\mathrm{N}$ limited systems. Harmful Algae 37, 84-91.

Cui, Y., Zhang, H. \& Lin, S. (2017). Enhancement of non-photochemical quenching as an adaptive strategy under phosphorus deprivation in the dinoflagellate Karlodinium veneficum. Frontiers in Microbiology 8: 1-14.

Daroch, M., Geng, S. \& Wang, G. (2013). Recent advances in liquid biofuel production from algal feedstocks. Applied Energy 102, 1371-1381.

Echigoya, R., Rhodes, L., Oshima, Y. \& Satake, M. (2005). The structures of five new antifungal and hemolytic amphidinol analogs from Amphidinium carterae collected in New Zealand. Harmful Algae 4(2), 383-389.

Gallardo-Rodríguez, J., Sánchez-Mirón, A., García-Camacho, F., LópezRosales, L., Chisti, Y. \& Molina-Grima, E. (2012). Bioactives from microalgal dinoflagellates. Biotechnology Advances 30(6), 1673-1684.

García-Camacho, F., Rodríguez, J.G., Mirón, A.S., García, M.C.C., Belarbi, E.H., Chisti, Y. \& Grima, E.M. (2007). Biotechnological significance of toxic marine dinoflagellates. Biotechnology Advances 25, 176-194. 
Garrido-Cardenas, J. A., Manzano-Agugliaro, F., Acien-Fernandez, F. G. \& Molina-Grima, E. (2018). Microalgae research worldwide. Algal Research 35, 50-60.

González-Rodríguez, J.J., Sanches-Mirón, A., García-Camacho, F., García, M.C., Belarbi, E.H. \& Molina-Grima, E. (2010). Culture of dinoflagellates in a fed-batch and continuous stirred-tank photobioreactors: Growth, oxidative stress and toxin production. Process Biochemistry 45(5), 660-666.

Gravinese, P. M., Kronstadt, S. M., Clemente, T., Cole, C., Blum, P., Henry, M. S., Pierce, R.H. \& Lovko, V. J. (2018). The effects of red tide (Karenia brevis) on reflex impairment and mortality of sublegal Florida stone crabs, Menippe mercenaria. Marine Environmental Research 137, 145-148.

Grégoire, V., Schmacka, F., Coffroth, M. A. \& Karsten, U. (2017). Photophysiological and thermal tolerance of various genotypes of the coral endosymbiont Symbiodinium sp. (Dinophyceae). Journal of Applied Phycology 29(4), 1893-1905.

Hallegraeff, G. M., Blackburn, S. I., Doblin, M. A. \& Bolch, C. J. S. (2012). Global toxicology, ecophysiology and population relationships of the chainforming PST dinoflagellate Gymnodinium catenatum. Harmful Algae $14,130-143$.

Hofmann, E., Wrench, P.M., Sharples, F.P., Hiller, R.G., Welte, W. \& Diederichs, K. (1996). Structural basis of light harvesting by carotenoids: peridinin-chlorophyll-protein from Amphidinium carterae. Science 272(5269), 1788-1791.

Holmes, M.J., Bolch, C.J., Green, D.H., Cembella, A.D. \& Teo, S.L.M. (2002). Singapore isolates of the dinoflagellate Gymnodinium catenatum (Dinophyceae) produce a unique profile of paralytic shellfish poisoning toxins 1. Journal of Phycology 38(1), 96-106.

Huang, S.J., Kuo, C.M., Lin, Y.C., Chen, Y.M. \& Lu, C.K. (2009). Carteraol E, a potent polyhydroxyl ichthyotoxin from the dinoflagellate Amphidinium carterae. Tetrahedron Letters 50(21), 2512-2515.

Iwamoto, M., Sumino, A., Shimada, E., Kinoshita, M., Matsumori, N. \& Oiki, S. (2017). Channel formation and membrane deformation via sterolaided polymorphism of amphidinol 3. Scientific Reports 7(1), 1-10.

Jeong, H.J., Du Yoo, Y., Kim, J.S., Seong, K.A., Kang, N.S. \& Kim, T.H. (2010). Growth, feeding and ecological roles of the mixotrophic and heterotrophic dinoflagellates in marine planktonic food webs. Ocean Science Journal 45(2), 65-91.

Jephcott, T.G., Sime-Ngando, T., Gleason, F.H. \& Macarthur, D.J. (2016). Host-parasite interactions in food webs: diversity, stability, and coevolution. Food Webs 6, 1-8.

Krueger, T. \& Gates, R. D. (2012). Cultivating endosymbionts-Host environmental mimics support the survival of Symbiodinium C15 ex hospite. Journal of Experimental Marine Biology and Ecology 413, 169176.

Lage, S., Costa, P.R., Moita, T., Eriksson, J., Rasmussen, U. \& Rydberg, S.J. (2014). BMAA in shellfish from two Portuguese transitional water bodies suggests the marine dinoflagellate Gymnodinium catenatum as a potential BMAA source. Aquatic Toxicology 152, 131-138.

LaJeunesse, T.C., Parkinson, J.E, Gabrielson, P.W., Jeong, H.J., Reimer, J.D., Voolstra, C.R., Santos, S.R. (2018). Systematic revision of Symbiodiniaceae highlights the antiquity and diversity of coral endosymbionts. Current Biology 28(16), 2570-2580.

Langenbach, D. \& Melkonian, M. (2019). Optimising biomass and peridinin accumulation in the dinoflagellate Symbiodinium voratum using a twin-layer porous substrate bioreactor. Journal of Applied Phycology 31(1), 21-28.

Legrand, C. \& Carlsson, P. (1998). Uptake of high molecular weight dextran by the dinoflagellate Alexandrium catenella. Aquatic Microbial Ecology 16(1), 81-86.

López-Rosales, L., García-Camacho, F., Sánchez-Mirón, A. \& Chisti, Y. (2015). An optimal culture medium for growing Karlodinium veneficum: Progress towards a microalgal dinoflagellate-based bioprocess. Algal Research 10, 177-182.
López-Rosales, L., García-Camacho, F., Sánchez-Mirón, A., Beato, E. M., Chisti, Y., \& Grima, E. M. (2016). Pilot-scale bubble column photobioreactor culture of a marine dinoflagellate microalga illuminated with light emission diodes. Bioresource Technology 216, 845-855.

López-Rosales, L., García-Camacho, F., Sánchez-Mirón, A., ContrerasGómez, A., \& Molina-Grima, E. (2017). Modeling shear-sensitive dinoflagellate microalgae growth in bubble column photobioreactors. Bioresource Technology 245, 250-257.

Martínez, K.A., Lauritano, C., Druka, D., Romano, G., Grohmann, T. Jaspars, M., Martín, J., Díaz, C., Cautain, B., Cruz, M., Ianora, A. (2019). Amphidinol 22, a new cytotoxic and antifungal amphidinol from the dinoflagellate Amphidinium carterae. Marine Drugs 17(7), 385.

Martínez, T.D.C.C., Rodríguez, R.A., Voltolina, D. \& Morquecho, L. (2016). Effectiveness of coagulants-flocculants for removing cells and toxins of Gymnodinium catenatum. Aquaculture 452, 188-193.

McIlroy, S.E., Gillette, P., Cunning, R., Klueter, A., Capo, T., Baker, A.C. \& Coffroth, M.A. (2016). The effects of Symbiodinium (Pyrrhophyta) identity on growth, survivorship, and thermal tolerance of newly settled coral recruits. Journal of Phycology 52(6), 1114-1124.

Mendes, A., Reis-Vasconcelos, A., Guerra, R.P., da Silva, T.L. (2009). Crypthecodinium cohnii with phasison DHA production: A review. Journal of Applied Phycology 21, 199-214.

Molina-Miras, A., López-Rosales, L., Sánchez-Mirón, A., Cerón-García, M.C., Seoane-Parra, S., García-Camacho, F. \& Molina-Grima, E. (2018). Longterm culture of the marine dinoflagellate microalga Amphidinium carterae in an indoor LED-lighted raceway photobioreactor: Production of carotenoids and fatty acids. Bioresource Technology 265, 257-267.

Molina-Miras, A., López-Rosales, L., Cerón-García, M. C., Sánchez-Mirón, A., Olivera-Gálvez, A., García-Camacho, F., \& Molina-Grima, E. (2020) Acclimation of the microalga Amphidinium carterae to different nitrogen sources: potential application in the treatment of marine aquaculture effluents. Journal of Applied Phycology 32, 1075-1094.

Muller-Fuega, A. (2000). The role of microalgae in aquaculture: situation and trends. Journal of Applied Phycology 2(5), 527-534.

Naylor, R., Goldburg, R.J.,Mooney, H.,Beveridge, M.,Clay, J.,Folke, C.,Kautsky, N., Lubchenco, J., Primavera, J. \& Williams, M. (1998). Nature's subsidies to shrimp and salmon farming. Science 282, 883-884.

Negri, A.P., Bolch, C.J.S., Blackburn, S.I., Dickman, M., Llewellyn, L.E., Méndez, S. (2001). Paralytic shellfish toxins in Gymnodinium catenatum strains from six countries. In: Hallegraeff, G.M., Blackburn, S.I., Bolch, C.J., Lewis, R.J. (Eds.), Harmful Algal Blooms 2000. Intergovernmental Oceanographic Commission of UNESCO, Paris, pp. 210-213.

Nishino, H. (1998). Cancer prevention by carotenoids. Mutation Research/Fundamental and Molecular Mechanisms of Mutagenesis 402(1-2), 159-163.

Oh, S.J., Kwon, H.K., Noh, I.H. \& Yang, H.S. (2010). Dissolved organic phosphorus utilization and alkaline phosphatase activity of the dinoflagellate Gymnodinium impudicum isolated from the South Sea of Korea. Ocean Science Journal 45(3), 171-178.

Oliveira, C.Y.B., Viegas, T.L., Lopes, R.G., Cella, H., Menezes, R.S., Soares, A.T., Antoniosi Filho, N. R. \& Derner, R.B. (2020a). A comparison of harvesting and drying methodologies on fatty acids composition of the green microalga Scenedesmus obliquus. Biomass and Bioenergy 132, 105437.

Oliveira, C.Y.B., Lima, J., Oliveira, C.D.L., Lima, P.C., Gálvez, A.O., \& Macedo Dantas, D. M. (2020b). Growth of Chlorella vulgaris using wastewater from Nile tilapia (Oreochromis niloticus) farming in a low-salinity biofloc system. Acta Scientiarum. Technology 42, e46232.

Panis, G. \& Carreon, J.R. (2016). Commercial astaxanthin production derived by green alga Haematococcus pluvialis: A microalgae process model and a techno-economic assessment all through production line. Algal Research 18, 175-190. 
Pan-Utai, W., Kahapana, W. \& Iamtham, S. (2018). Extraction of Cphycocyanin from Arthrospira (Spirulina) and its thermal stability with citric acid. Journal of Applied Phycology 30(1), 231-242.

Parker, N.S., Negri, A.P., Frampton, D.M.F., Rodolfi, L., Tredici, M.R. \& Blackburn, S.I. (2002). Growth of the toxic dinoflagellate Alexandrium minutum (Dinophyceae) using high biomass culture systems. Journal of Applied Phycology 14(5), 313-324.

Place, A.R., Bowers, H,A., Bachvaroff, T.R., Adolf, J.E., Deeds, J.R. \& Sheng, J. (2012). Karlodinium veneficum - The little dinoflagellate with a big bite. Harmful Algae 14, 179-195.

Proença, L.A.O., Tamanaha, M.S. \& Souza, N.P. (2001). The toxic dinoflagellate Gymnodinium catenatum Graham in southern Brazilian waters: occurrence, pigments and toxins. Atlântica 23, 59-65.

Salama, E., Kurade, M.B., Abou-Shanab, R.A., El-Dalatony, M.M., Yang, I.S., Min, B. \& Joen, B.H. (2017). Recent progress in microalgal biomass production coupled with wastewater treatment for biofuel generation. Renewable and Sustainable Energy Reviews 79, 1189-1211.

Saldarriaga, J.F. \& Taylor, F.J.R. (2017). Dinoflagellata. Handbook of the Protists, 625-678.

Satake, M., Cornelio, K., Hanashima, S., Malabed, R., Murata, M., Matsumori, N., Zhang, H., Hayashi, F., Mori, S., Kim, J.S., Kim, C. H. \& Lee, J.S. (2017). Structures of the largest amphidinol homologues from the dinoflagellate Amphidinium carterae and structure-cctivity relationships. Journal of Natural Products 80(11), 2883-2888.

Spatharis, S., Danielidis, D.B. \& Tsirtsis, G. (2007). Recurrent Pseudonitzschia calliantha (Bacillariophyceae) and Alexandrium insuetum (Dinophyceae) winter blooms induced by agricultural runoff. Harmful Algae 6, 811-822.

Steidinger, K. \& Janger, K. (1996). Identifying marine diatoms and dinoflagellates. In: Tomas, C.R. Dinoflagellates. vol. 2, Academic press, New York, p.606.

Suggett, D.J., Warner, M.E. \& Leggat, W. (2017). Symbiotic dinoflagellate functional diversity mediates coral survival under ecological crisis. Trends in Ecology \& Evolution 32(10), 735-745.

Touzet, N., Franco, J.M. \& Raine, R. (2008). Morphogenetic diversity and biotoxin composition of Alexandrium (Dinophyceae) in Irish coastal waters. Harmful Algae 7(6), 782-797.

Tsirigoti, A., Tzovenis, I., Koutsaviti, A., Economou-Amilli, A., Ioannou, E. \& Melkonian, M. (2020). Biofilm cultivation of marine dinoflagellates under different temperatures and nitrogen regimes enhances DHA productivity. Journal of Applied Phycology 1-16.

Wang, D.Z. \& Hsieh, D.P. (2002). Effects of nitrate and phosphate on growth and C2 toxin productivity of Alexandrium tamarense CI01 in culture. Marine Pollution Bulletin 45(1-12), 286-289.

Waters, A.L., Hill, R.T., Place, A.R. \& Hamann, M.T. (2010). The expanding role of marine microbes in pharmaceutical development. Current Opinion in Biotechnology 21, 780-786.

Zeller, M.A., Hunt, R., Jones, A. \& Sharma, S. (2013). Bioplastics and their thermoplastic blends from Spirulina and Chlorella microalgae. Journal of Applied Polymer Science. v. 130, p. 3263-3275. 